\author{
Nota científica \\ (Short communication)
}

\title{
LEUCISM IN REITHRODONTOMYS MEXICANUS SOEDERSTROEMI (RODENTIA: CRICETIDAE), QUITO, ECUADOR
}

\section{LEUCISMO EN REITHRODONTOMYS MEXICANUS SOEDERSTROEMI (RODENTIA: CRICETIDAE), QUITO, ECUADOR}

\author{
SAlomón M. RAMÍREZ JARAMILlO ${ }^{1}$, PATRICIA BEJARANO MUÑOZ ${ }^{1}$, ANGÉlica CAIZA², Marilyn \\ NOVILLO ${ }^{3}$, PABLO MORENO CÁRDENAS $^{1 *}$ \\ ${ }^{1}$ Instituto Nacional de Biodiversidad (INABIO), Rumipamba 341 y Av. De los Shyris, Quito, Ecuador. <kp-7sz@hotmail.com>; \\ <coorozzo@hotmail.com>; <pablo.moreno@biodiversidad.gob.ec, morencard@ hotmail.com> \\ ${ }^{2}$ University of Groningen, PhD candidate, Faculty of Spatial Science, PO Box 8009700 Av. Groningen, the Netherlands. \\ $<$ m.a.caiza.villegas@rug.nl> \\ ${ }^{3}$ Department of Biology and Marine Biology, University of North Carolina Wilmington UNCW, Wilmington, North Carolina. \\ <marylinnovillo@gmail.com> \\ *Autor de correspondencia:<morencard@hotmail.com>
}

Recibido: 27/09/2018; aceptado: 09/07/2019; publicado en línea: 20/09/2019

Editor responsable: Alberto González Romero

Ramírez-Jaramillo, S., Bejarano-Muñoz, P., Caiza, A., Novillo, M., Moreno-Cárdenas, P. (2019) Leucism in Reithrodontomys mexicanus soederstroemi (Rodentia: Cricetidae), Quito, Ecuador. Acta Zoológica Mexicana (nueva serie), 35, 1-4. https://doi.org/10.21829/azm.2019.3502078

\begin{abstract}
Leucism is a hypopigmentary decrease of skin or fur coat, which is presented throughout the body or as isolated whitish patches on different parts of the body "piebald"; without altering the pigmentation of the eyes, lips, blood vessels or harm to the immune system of the specimen. The specimen was identified in the Tababela plateau located in the inter-Andean valley of Pichincha, Ecuador, site of the new Quito airport. By using glue traps used to capture lizards, one individual of Reithrodontomys mexicanus soederstroemi showing leucism, was trapped in the wild. This individual presents an irregular distribution of melanin pigments throughout it's body. This is the first case reported with leucism in nature for this endemic species of the inter-Andean xeric valleys near Quito.
\end{abstract}

Ramírez-Jaramillo, S., Bejarano-Muñoz, P., Caiza, A., Novillo, M., Moreno-Cárdenas, P. (2019) Leucismo en Reithrodontomys mexicanus soederstroemi (Rodentia: Cricetidae), Quito, Ecuador. Acta Zoológica Mexicana (nueva serie), 35, 1-4. https://doi.org/10.21829/azm.2019.3502078

RESUMEN. El leucismo es una disminución hipopigmentaria general, presente en la piel o pelo de todo el cuerpo de un animal, o en ocasiones, se presenta como parches blanquecinos en diferentes partes del cuerpo; sin alterar la pigmentación de los ojos, labios, vasos sanguíneos o perjudicar al sistema inmunológico del ejemplar que lo porta. En la plataforma de Tababela donde se construyó el nuevo aeropuerto de Quito localizado en el valle interandino de Pichincha, Ecuador; mediante el uso de trampas de goma usada para capturar herpetofauna, fue capturado un individuo de Reithrodontomys mexicanus soederstroemi que muestra leucismo. El individuo presenta una distribución irregular del pigmento de melanina en todo su 
Ramírez-Jaramillo et al.: Leucism in Reithrodontomys mexicanum

soederstroemi, Ecuador

cuerpo. Este es el primer caso de una especie silvestre endémica reportada con leucismo en un valle seco interandino cerca de Quito.

Albinism in rodents is the result of deficiency of pigmentation in skin, hair and eyes. It can vary from total absence of melanin to partial absence. The organisms that have partial albinism present a wide range of tones (Beermann et al., 2004). The leucism, is a hypopigmentary variation of skin or fur coat, which is presented throughout the body (Martínez-Coronel et al., 2013) or as isolated patches on different parts of the body "piebald" (Metallinos et al., 1994; Treitler et al., 2013; Camargo et al., 2014). Unlike albinism, leucism is characterized by not affecting the pigmentation of eyes, lips and blood vessels and it does no reduce the immune system's defense function (Robinson, 1973; Slominski et al., 2004). Leucism in small mammals is not necessarily the result of genetic mutations (Beermann et al., 2004; Treitler et al., 2013), alterations in their nutritional conditions (Treitler et al., 2013) or the isolation of their habitats (Nedyalkov et al., 2014). Rather leucism appears to be more common in some mammal populations because of the variability in melanin production of melanocytes at the base of the fur, this changes throughout the life of an organism (Slominski et al., 2004).

Until 2016, only 38 cases of leucism in rodents has been reported in Ecuador. These reports identified eight different species (Akodon mollis, Nephelomys albigularis, Nephelomys moerex, Transandinomys talamancae, Thomasomys auricularis, Thomasomys taczanowskii, Thomasomys paramorum and Mesomys hispidus) from five genera (Brito \& Valdivieso-Bermeo, 2016), concluding that the occurrence of leucism cases are related to fragmentation and degradation of natural habitats without strong arguments.

In this note, we present a case of leucism in Reithrodontomys mexicanus soederstroemi (Thomas, 1898) occurred in a valley near Quito.

A fauna survey was conducted from 2011 to 2015 (with samples every two months). Approximately 2,880 night/traps were completed in an effort to capture small mammals with 30 Sherman traps, as part of the ecological assessments study. The objective was to identify the variation in the populations of mammals during the construction of the new Quito airport, along the Tababela plateau with almost 1,977 acres of altered and populated area, located east of the city of Quito, Pichincha province. Most voucher specimens were deposited at the Instituto Nacional de Biodiversidad before Museo Ecuatoriano de Ciencias Naturales (MECN). The study area is located in the semi-deciduous (xeric) forest and shrub land ecosystem of the northern interandean valleys (Ministerio del Ambiente del Ecuador, 2013) at $00.10983^{\circ} \mathrm{S}, 78.36986^{\circ} \mathrm{W}$, $2,443 \mathrm{~m}$ altitude. The study area has sparse xerophytic vegetation cover and is surrounded by steep ravines. One specimen of $R$. m. soederstroemi with leucism (Fig. 1b) was collected at 23:45 hours, accidentally by the herpetology team, The glue traps were originally placed to capture saurians (Bauer \& Sadlier, 1992; Blomberg \& Shine, 2006).

Reithrodontomys $\mathrm{m}$. soederstroemi was the most abundant captured rodent during the mammal monitoring. Throughout the study, 317 individuals of this species were captured in the same area. Normally, the specimens of $R$. m. soederstroemi, captured in the area, have a dark brown coloration on the back, neck and head, scattered with black whole hairs, except for a whitish or orange tuft behind the ears. The tail is covered in dark scales and the tip of the tail ends as white "pencil". On the sides of the body it has a roseorange coloration with whitish throughout the ventral region including the snout, jaw, hands and feet (Fig. 1a). This coincides with the coloration described for this species (Hershkovitz, 1941).

Of all specimens of $R$. m. soederstroemi captured throughout the process, only one individual accidentally caught on May 18, 2013, presented leucism. Almost the entire fur showed a white tone in the dorsal side, both sides of the body and ventral side (chest and abdomen). The edge of the tail showed greyish 
tones in fur (Fig. 1b), without compromising the normal coloration of the skin, limbs, ears, tail and eyes. This individual was captured and photographed. However, unfortunately, the specimen escaped, and therefore, was not collected as a voucher for a scientific collection.

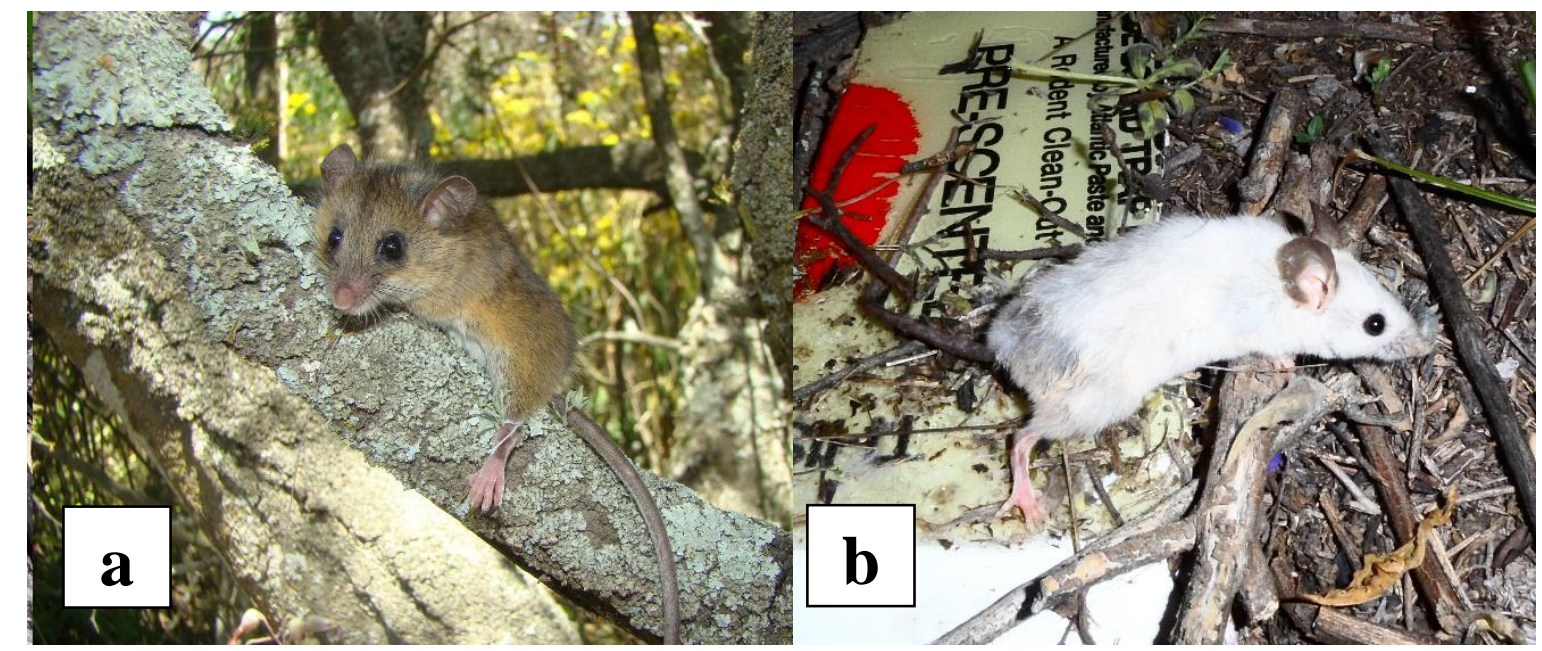

Figure 1. Comparison between (a), R. m. soederstroemi, normal coat-color (MECN 3485) photo Pablo Moreno; Tababela, Quito. and (b) R. m. soederstroemi with leucism, photo by Salomón Ramírez (individual escaped at the time of its capture); Pichincha, Quito, Tababela.

In the genus Reithrodontomys, there are cases of continuous albinism in captive-bred specimens (Egoscue, 1958), and have been reported showing that it is a recessive condition, when related specimens are crossed.

The evidence of the current report showed that a leucism specimen, one of $317(0.3 \%)$ suggests a low probability of registering this singularity in the area for this native species. It is also possible that specimens with atypical coloration (white) in the wild are under high predation in comparison with individuals with normal colorations. This is due to the fact that they are more visible to their predators (Camargo et al., 2014; Nedyalkov et al., 2014), thus reducing the probability of transferring the pleiotropic genes (that alone transmit a phenotypic character) associated with leucism to future generations (Egoscue, 1958; Nedyalkov et al., 2014). This is the only registered case within five years of monitoring.

Our specimen, therefore represents the first report of leucism in Ecuador for this species contributing to the knowledge of this Neotominae endemic species within the valleys of Quito (Arellano, 2015; Chávez 2012; Moreno et al., 2017, Romero et al., 2018).

More information on leucism would help us to establish a greater degree of accuracy on this matter. It is important to carry out more studies at the genetic level, in order to further understand the genetic variation of leucism in different species of small mammals and determine the circumstances for these variations of coloration in some rodent populations of Ecuador.

AKNOWLEDGements. We are especially grateful to C. Garzón from the Ornithology Department of the National Institute of Biodiversity of Ecuador (INABIO) for the facilities provided for biological study in the Tababela region, location of the new International Airport of Quito. Financial support was generously provided by the QUIPORT Corporation and R. Calderón. We also would like to thank D. Proaño for help during the field trip, L. Garzón for his logistical support, M. Yánez for his comments and suggestions and D. Moreno for reviewing the wording of the document. 
Ramírez-Jaramillo et al.: Leucism in Reithrodontomys mexicanum

soederstroemi, Ecuador

\section{LITERATURED CITED}

Arellano, E. (2015) Genus Reithrontomys Giglioli, 1874, pp. 61-63. In: Patton, J., Pardiñas, U. (Eds.). Mammals of South America. University of Chicago Press. Illinois, EE.UU.

Bauer, A. M., Sadlier, R. A. (1992) The use of mouse glue traps to capture lizards. Herpetological Review, 23, 112-113.

Beermann, F., Orlow, S. J., Lamoreux, M. L. (2004). The Tyr (albino) locus of the laboratory mouse. Mammalian Genome, 15, 749-758.

Blomberg, S., Shine, R. (2006) Reptiles, pp. 297-307. In: Sutherland, W. J. (Ed). Ecological Census Techniques. Cambridge University Press. Cambridge, UK.

Brito, J., Valdivieso-Bermeo, K. (2016) First records of leucism in eight species of small mammals (Mammalia: Rodentia). Therya, 7, 483-489.

https://doi.org/10.12933/therya-16-408

Camargo, I., Rios, E., Cornejo-Latorre, C., Álvarez-Castañeda, S. T. (2014) First Record of Leucism in the Genus Peromyscus (Mammalia: Rodentia). Western North American Naturalist, 74, 366-368. https://doi.org/10.3398/064.074.0301

Chávez, D. (2012) Diferenciación morfológica y genética de las poblaciones del ratón cosechador mexicano (Reithrodontomys mexicanus Seassure, 1860 Rodentica: Cricetidae) en los Andes del Ecuador. Tesis de Licenciatura. Pontificia Universidad Católica del Ecuador. http://repositorio.puce.edu.ec/handle/22000/4930

Egoscue, H. J. (1958) Albinism in the western harvest mouse. Journal of Mammalogy, 39, 306.

Hershkovitz, P. (1941) The South American harvest mice of genus Reithrodontomys. Occasional Papers of the Museum of Zoology, 411, 1-7.

Martínez-Coronel, M., Bautista, R., Verona-Trejo, M. I. (2013) Albinismo platinado en Liomys pictus (Mammalia: Heteromyidae). Therya, 4, 641-645. https://doi.org/10.12933/therya-13-149

Metallinos, D. L., Oppenheimer, A. J., Rinchik, E. M., Russell, L. B., Dietrich, W., Tilghman, S. M. (1994) Fine Structure Mapping and Deletion Analysis of the Murine. Genetics, 136, 217-223.

Ministerio del Ambiente del Ecuador (MAE) (2013) Sistema de Clasificacion de los Ecosistemas del Ecuador Continental. Subsecretaria de Patrimonio Natural. Quito, Ecuador.

Moreno, P., Roman, J. L., Brito, J., Pardiñas, U. J. F. (2017) The taxonomic status of Copemyodon ecuadorensis (Rodentia:Cricetidae), supposedly extinct muroid from Ecuadorean Quaternary. Mammalia, 82, 89-92.

Nedyalkov, N., Koshev, Y., Raykov, I., Bardarov, G. (2014) Color variation of small mammals's (Mammalia: Rodentia and Insectivora) coats from Bulgaria. North-Western Journal of Zoology, 10, 314-317.

Robinson, R. (1973) Acromelanic albinism in mammals. Genetica, 44, 454-458. https://doi.org/10.1007/BF00161317

Romero, V., Racines-Márquez, C. E., Brito, J. (2018) A short review and worldwide list of wild albino rodents with the first report of albinism in Coendou rufescens (Rodentia: Erethizontidae). Mammalia, 82 (5), 1-7. https://doi.org/10.1515/mammalia-2017-0111

Slominski, A., Tobin, D. J., Shibahara, S., Wortsman, J. (2004) Melanin Pigmentation in Mammalian Skin and Its Hormonal Regulation. Physiological Reviews, 84, 1155-1228. https://doi.org/10.1152/physrev.00044.2003

Treitler, J. T., Baucells, A. L., Gomez-Farias, S., Tenacol, J. F. J., Rocha, R. (2013) First record of leucist piebald Phyllostomus discolor (Chiroptera: Phyllostomidae). Chiroptera Neotropical, 19, $1179-1181$.

https://doi.org/10.1644/801.1 